\title{
Identification of the bovine $\alpha 1$-acid glycoprotein in colostrum and milk
}

\author{
Fabrizio CECILIANI*, Vanessa PoCACQUA, Elena PROVASI, \\ Claudio COMUnian, Alessandra BerTOLInI, Valerio BronZO, \\ Paolo MORONI, Paola SARTORELLI \\ Dipartimento di Patologia Animale, Igiene e Sanità Pubblica Veterinaria, University of Milan, \\ via Celoria 10, 20133 Milano, Italy
}

(Received 15 October 2004; accepted 21 February 2005)

\begin{abstract}
AGP) is an immunomodulatory protein expressed by hepatocytes in response to the systemic reaction that follows tissue damage caused by inflammation, infection or trauma. This paper presents the detection of bovine AGP (boAGP) in mammary secretions (colostrum and milk) and mammary gland tissue. Bovine AGP was detected by Western blotting in all the samples analysed, and could be quantified in colostrum at $162( \pm 63.7) \mu \mathrm{g} / \mathrm{mL}$ and 114.5 $( \pm 67.8) \mu \mathrm{g} / \mathrm{mL}$ during the first $12 \mathrm{~h}$ and $24 \mathrm{~h}$ respectively. In mature milk, the boAGP concentration clearly decreased and was no longer detectable using the Radial Immunodiffusion (RID) technique. The concentration of mature milk boAGP was therefore semi-quantified using an anion-exchange chromatographic procedure that allowed the concentration of the protein to be determined. The presence of AGP in bovine milk was confirmed by the internal sequence analysis performed following purification to homogeneity of the protein from milk. The concentration of AGP in bovine milk with low SCC $(<250000)$ was very similar to that from bovine milk with high SCC $(>250000)$. In order to investigate the origin of AGP in bovine milk, a search for mRNA was carried out in somatic cells and mammary gland tissue: mRNA expression of the boAGP gene was detected in mammary gland tissue, but not in somatic cells. Finally, the cDNA sequence of the boAGP was determined, and is hereby presented.
\end{abstract}

$\alpha 1$-acid glycoprotein / mastitis / colostrum / milk

\section{INTRODUCTION}

Several bovine milk proteins, including casein components, whey proteins $(\alpha-$ lactalbumin for example) and other peptides, have an immunomodulatory activity [9]. It is likely that the biological function of these peptides is not only to regulate the immune function of the newborn, but also to modulate, i.e. enhance or inhibit, the inflamma- tory reactions during infections. In fact the mechanisms that usually protect the udder from infection can also cause extensive tissue injury and these collateral damages that accompany mastitis are often responsible for severe lesions to the mammary epithelium [1].

The aim of this paper was to investigate the expression of $\alpha 1$-acid glycoprotein (AGP) in bovine colostrum and mature milk.

\footnotetext{
* Corresponding author: fabrizio.ceciliani@unimi.it
} 
AGP belongs to the "lipocalins" family, a group of proteins that are deputed to the binding and transport of small hydrophobic molecules [6]: AGP has been further classified in a subset of lipocalins, the so called "immunocalins", a subfamily of proteins that may also immunomodulate the inflammatory reaction [19].

Therefore, AGP features at least two different biological activities, apparently very different from each other: AGP may immunomodulate the inflammatory response, and, meanwhile, act as a plasma transport protein [8, 13].

Bovine AGP (boAGP) is a glycoprotein of $42 \mathrm{kDa}$, as determined by SDS-PAGE, the carbohydrate moiety accounting for $26.6 \%$ of its molecular weight [30]. More recently the MW of boAGP was fixed to $33.8 \mathrm{kDa}$ by MALDI-TOF mass spectrometry analysis [23].

From a clinical perspective, AGP belongs to the Acute Phase Proteins (APP), a structurally un-related group of mainly liverderived plasma proteins that are associated with an acute phase reaction $[10,26]$. AGP is considered as a minor acute phase protein in cattle since its concentration increases only two- to four-fold during inflammation [30]. As the other acute phase proteins, AGP is produced mainly by hepatic cells, but local expression has been reported in human breast epithelial cells [11], stimulated alveolar macrophages [7] and human endothelial cells [29]. The detection of two of the major bovine APP, haptoglobin and serum amyloid A (SAA) in milk during mastitis [5] may suggest a role for APP also in the immunomodulation of the local inflammatory reaction in the udder. Among the several immunomodulatory activities that have been proposed for AGP [13], some of them including the control of neutrophil activity [34] and the expression of several cytokines during inflammation [31] might play an important role in the context of intramammary defences against microorganisms [28]. Bovine AGP may therefore represent a conceivable candidate to be one of several host factors that regulate the recruitment from blood of immune cells, and their rate of activation.

This paper presents the detection of AGP in bovine colostrum and mature milk. In order to investigate the origin of boAGP in milk, i.e. whether the protein is produced by milk somatic cells, the mammary gland or derived from plasma extravasation, a search for mRNA has been carried out in both somatic and mammary gland tissue. As a preliminary step towards elucidating the correlation between the structure and function of boAGP, the cDNA sequence of the boAGP gene was also determined.

\section{MATERIALS AND METHODS}

\subsection{Animals}

Colostrum samples were collected after $12 \mathrm{~h}, 24 \mathrm{~h}, 3$ days and 5 days post-partum from 10 clinically healthy dairy cows (Holstein Friesian).

Mature milk samples were collected from 18 clinically healthy Holstein Friesian dairy cows, divided on the basis of the somatic cell counts (SCC) into two groups:

Group A: 11 animals with a SCC < 250000 cells $/ \mathrm{mL}$.

Group B: 7 animals with a SCC > 251000 cells/mL.

Group B animals were considered as having mastitis. Three mammary gland samples were used for detection of boAGP mRNA from mammary tissue, and were collected at the slaughterhouse from healthy animals, with a normal somatic cell count $(<250000)$ and no evidence of clinical mastitis or other diseases. Mammary gland samples were stored in RNAlater (Qiagen S.p.A., Milano, Italy). Three liver samples, which were used for the determination of the cDNA sequence of AGP and as a positive control throughout PCR experiments, were collected from healthy animals, immediately frozen using liquid nitrogen and successively stored at $-80^{\circ} \mathrm{C}$. 


\subsection{Bacteriological procedures}

Milk samples $(10 \mu \mathrm{L})$ were spread on blood agar plates (5\% defibrinated bovine blood). The plates were incubated aerobically at $37{ }^{\circ} \mathrm{C}$ and examined at $24 \mathrm{~h}$ post seeding. The colonies were provisionally speciated based on morphology, haemolysis pattern and Gram stain. The numbers of each distinct colony type were recorded. The representative colonies were subcultured on blood agar plate and incubated aerobically at $37^{\circ} \mathrm{C}$ to obtain pure colonies. Gram positive cocci were tested for catalase and coagulase production. Mastitis status of milk samples was determined by diagnostic procedures recommended by the National Mastitis Council.

\subsection{Determination of somatic cell counts (SCC)}

The SCC were determined for each milk sample by an automated fluorescent microscopic somatic cell counter (Bentley Somacount 150, Bentley Instruments, USA). Ethidium bromide dye was used for specific binding to the DNA in the cell nuclei.

\subsection{Detection of boAGP in milk and colostrum}

The concentration of boAGP was determined using a radial immunodiffusion assay commercial kit (Bovine $\alpha 1$ AG Plate, Tridelta Development Ltd., Maynooth, Ireland). Two experiments were performed:

(a) Determination of boAGP from whey: milk and colostrum whey were prepared as follows: $10 \mathrm{~mL}$ of mammary secretions were centrifuged at $1200 \times g$ for $15 \mathrm{~min}$ at $4{ }^{\circ} \mathrm{C}$ in order to remove fat and cells. Four millilitres of whey were further centrifuged at $13000 \times g$ at RT, and $5 \mu \mathrm{L}$ of the supernatant was used following kit instruction.

(b) Determination of boAGP from whey after Q-Sepharose chromatography: whey was prepared as previously described. Four millilitres of whey after $13000 \times g$ centrifugation were dialyzed overnight against the starting buffer used for the chromatography (10 mM citrate-phosphate buffer, $\mathrm{pH} 4.0$ ) at $4{ }^{\circ} \mathrm{C}$. The dialyzed solution was then centrifuged at $13000 \times g$ for $5 \mathrm{~min}$ in order to remove insoluble proteins, and the supernatant was finally applied onto HPLC (Jasco, Great Dunmow, UK) equipped with an HiTrap Q Sepharose XL (7/25 mm) strong anionic exchange column (Amersham Biosciences, Nerviano, Italy), that exploits the low pI of AGP (3.2 to 3.7), and equilibrated with the starting buffer. The column was washed with the same buffer and the protein was eluted with $100 \mathrm{mM}$ citrate-phosphate buffer, $\mathrm{pH}$ 4.0. The elution was monitored at $280 \mathrm{~nm}$. The fraction containing boAGP (approximately $1 \mathrm{~mL}$ ) was dried with Centricon 30 (Millipore, Vimercate, Italy), resuspended in $50 \mu \mathrm{L}$ and $5 \mu \mathrm{L}$ of this concentrated protein solution was used following the bovine AGP detection kit instructions.

\subsection{Electrophoresis and Western blotting}

Fractions containing boAGP $(15 \mu \mathrm{g}$ total proteins) were subjected to SDS-PAGE $(12 \%$ polyacrylamide gels) in a discontinuous $\mathrm{pH}$ system [17] using a Miniprotean II apparatus (Bio-Rad, Segrate, Italy). The protein concentrations were determined using a Bradford Assay (Bio-Rad, Segrate, Italy). Western blotting was performed with a mini trans blot electrophoresis cell (BioRad, Segrate, Italy) onto nitrocellulose. Bovine AGP was detected with an anti-feline AGP polyclonal antibody raised in sheep which was generously provided by Dr Addie (Department of Veterinary Pathology, University of Glasgow, United Kingdom) and an alkaline phosphatase-conjugated goat anti-sheep secondary antibody. The crossreactivity of anti-feline AGP antibody with boAGP was tested using a commercial boAGP (Sigma, Milano, Italy) as a positive control. The blots were developed using the Amplified AP Immun-Blot Kit (Bio-Rad, Segrate, Italy). 
Table I. The degenerate primers used for cDNA sequencing of bovine AGP.

\begin{tabular}{lccc}
\hline & Primer & Sequence & Size (bp) \\
\hline First pair of primers & AGP1 F & CCYATCACCAAYGMSACC & 18 \\
& AGP1 R & GCRTAGAVRGASAGYCCC & 18 \\
Second pair of primers & AGP1 F1 & ACCAGTGYRTCTATAAC & 17 \\
& AGP1 R1 & TTTATTGATGCAASTGAGGGA & 21 \\
Third pair of primers & AGP F3 & ATGGCACAAAGAACGTGG & 18 \\
& AGP R3b & TTTATTGATGCAASTGAGGGA & 21 \\
Fourth pair of primers & AGP1 F2 & ATGGCGCTGYMCWSGG & 16 \\
& AGP1 R2 & GTGGCATTGGTGATGGG & 17 \\
\hline
\end{tabular}

\subsection{Purification and aminoacid sequence analysis of the purified boAGP from milk}

The purification of AGP from bovine milk was carried out starting from $100 \mathrm{~mL}$ of whey. Q-Sepharose chromatography was performed as previously described, and the eluted fractions $(50 \mathrm{~mL})$ were concentrated with Centricon 30 (Millipore, Vimercate, Italy) to $5 \mathrm{~mL}$ and loaded onto a Poros Heparin Affinity $(20 \mu \mathrm{m} 4.6 / 100 \mathrm{~mm})$ chromatographic column (Applied Biosystems, Monza, Italy) at a flow rate of $5 \mathrm{~mL} / \mathrm{min}$. The column was previously equilibrated in TrisHCl $10 \mathrm{mM}, \mathrm{pH}$ 7.6. In these conditions boAGP is not retained by the column and is therefore eluted in a void volume. The fraction containing AGP $(35 \mathrm{~mL})$ was directly loaded on a Sephasil Protein C4 (5 $\mu \mathrm{m}$ ST $4.6 / 100 \mathrm{~mm}$ ) chromatographic column (Amersham Biosciences, Nerviano, Italy) equilibrated with $0.065 \%$ TFA in $2 \%$ acetonitrile. Protein separation was accomplished using a $0-65 \%$ gradient of acetonitrile + $0.05 \%$ TFA over $33 \mathrm{~min}$, at a flow rate of $1 \mathrm{~mL} / \mathrm{min}$. The fraction containing boAGP, which was eluted after $20 \mathrm{~min}$, was finally concentrated to $1 \mathrm{mg} / \mathrm{mL}$ and submitted to sequence analysis. Sequence analysis was carried out on an Applied Biosystems Procise Sequencer. Purified boAGP (1 nmol) was subjected to automated Edman degradation. In order to obtain internal amino acid sequences, SDS-PAGE samples (2 nmol) were electrophoresed on $12 \%$ SDS- polyacrylamide gel and blotted onto a polyvi- nylidene difluoride (PVDF) membrane as described [20]. The blots were stained with Coomassie Blue and excised bands were submitted to in situ $\mathrm{CNBr}$ fragmentation as described in [2] directly on a TFA-treated glass fiber disk used for sample loading. The sequence obtained was overlapped to the cDNA sequence of boAGP.

\subsection{Determination of boAGP gene sequence}

Total RNA was extracted from the bovine liver using the RNeasy Mini Kit (Qiagen, Milano, Italy). The reverse transcription (RT) reaction was carried out using Ready To Go Your-Prime First-Strand Beads (Amersham Biosciences, Nerviano, Italy) and the primers Random Hexamers and Oligo dT. The thermal profile was as follows: $50 \mathrm{~min}$ at $42{ }^{\circ} \mathrm{C}$ and $15 \mathrm{~min}$ at $70{ }^{\circ} \mathrm{C}$. The cDNA was used as the template for the PCR (Eppendorf Mastercycler ${ }^{\circledR}$ ). PCR reactions were performed in $10 \mu \mathrm{L}$ final volumes under the following condition: $1 \mathrm{X}$ buffer Eppendorf, $1.5 \mathrm{mM} \mathrm{MgCl}_{2}, 0.2 \mathrm{mM}$ of each dNTP, $1 \mu \mathrm{M}$ of each primer and 0.5 unit of Taq Polymerase (Eppendorf, Milano, Italy). The primers used to amplify the coding sequence of bovine AGP are listed in Table I and were obtained following the alignment of the known AGP cDNA sequence available in Genbank, i.e. man (M13692), mouse (M17376), rat (J00696), pig (M35990). The thermal profile (35 cycles) was as follows: pre-PCR of $2 \mathrm{~min}$ at $94^{\circ} \mathrm{C}$; denaturation for $45 \mathrm{~s}$ at $94{ }^{\circ} \mathrm{C}$; annealing for $50 \mathrm{~s}$ at $56^{\circ} \mathrm{C}$ 
for the first, $45^{\circ} \mathrm{C}$ for the second and $53{ }^{\circ} \mathrm{C}$ for the third pairs of primers; extension for $80 \mathrm{~s}$ at $72{ }^{\circ} \mathrm{C}$; final $10 \mathrm{~min}$ extension at $72{ }^{\circ} \mathrm{C}$. The thermal protocol applied for the fourth pair of primers was a Touch-down PCR: pre-PCR of $60 \mathrm{~s}$ at $94{ }^{\circ} \mathrm{C} ; 8$ cycles of denaturation for $30 \mathrm{~s}$ at $94^{\circ} \mathrm{C}$; annealing for $45 \mathrm{~s}$ at $58^{\circ} \mathrm{C}$ and extension for $80 \mathrm{~s}$ at $60{ }^{\circ} \mathrm{C}$ followed by 32 cycles of denaturation for $30 \mathrm{~s}$ at $94{ }^{\circ} \mathrm{C}$; annealing for $45 \mathrm{~s}$ at $55^{\circ} \mathrm{C}$ and extension for $80 \mathrm{~s}$ at $60{ }^{\circ} \mathrm{C}$; then a final extension at $72{ }^{\circ} \mathrm{C}$ for $5 \mathrm{~min}$.

PCR products were applied on a $2 \%$ agarose gel electrophoresis and the segments of predicted molecular weight obtained were gel-purified using the QIAquick gel extraction kit (Qiagen, Milano, Italy) and then were quantified. The fragments were sequenced directly with ABI technology using an automated DNA sequencer (ABI PRISM 310 Genetic Analyzer). The predicted amino acid sequence was obtained using the ExPASy proteomic server.

\subsection{Detection of AGP mRNA from cells and mammary tissue}

Aliquots of the total RNA samples were prepared from bovine liver (used throughout the experiment as positive controls for the expression of boAGP), the somatic cells (all 18 milk samples) and three mammary gland samples using the RNeasy Mini Kit (Qiagen, Milano, Italy).

Somatic cells were purified as described by [18]. cDNA synthesis was performed by using Ready To Go Your-Prime First-Strand Beads (Amersham Biosciences, Nerviano, Italy) and oligo dT primers. Since mammary tissue stored in RNAlater solution revealed a partial degradation of RNA, two different set of primers (Tab. I) were used. Primers AGPF and AGPR were used for somatic and liver cells, and primers AGPF3 and AGPR3b were used for mammary tissue and liver cells. One microlitre of cDNA was amplified by PCR. The amplifications of somatic cells and liver cDNA were performed using 35 cycles of $94{ }^{\circ} \mathrm{C}$ for $45 \mathrm{~s}$

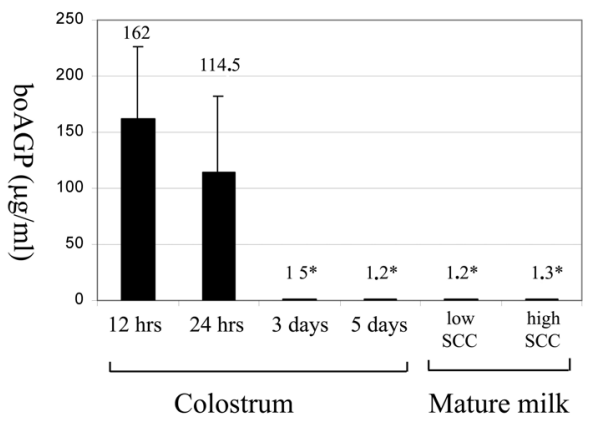

Figure 1. AGP concentration in bovine colostrum and milk. Concentration of AGP in bovine colostrum (12 h, 24 h, 3 days, 5 days) from 10 cows (colostrum) and 12 cows (mature milk). The data of mean concentration $(\mu \mathrm{g} / \mathrm{mL})$ are shown as means \pm St.Dev. The asterisks $(*)$ indicate that samples have been previously concentrated (approximately 80 fold) by anion exchange chromatography and ultrafiltration, as described in the Materials and methods section.

(denaturation), $56{ }^{\circ} \mathrm{C}$ for $40 \mathrm{~s}$ (annealing) and $72{ }^{\circ} \mathrm{C}$ for $80 \mathrm{~s}$ (extension). The conditions for the amplification of mammary tissue were the same, with the exception of the annealing step $\left(53^{\circ} \mathrm{C}\right.$ for $\left.40 \mathrm{~s}\right)$. The amplified products were analysed on $2 \%$ agarose gels.

\section{RESULTS}

\subsection{Quantification of boAGP in milk and colostrum}

Bovine AGP was directly detected in all whey samples from colostrum withdrawn after $12 \mathrm{~h}(162 \mu \mathrm{g} / \mathrm{mL} \pm 63.7 \mu \mathrm{g} / \mathrm{mL})$ and $24 \mathrm{~h}(114.5 \mu \mathrm{g} / \mathrm{mL} \pm 67.8 \mu \mathrm{g} / \mathrm{mL})$ (Fig. 1). Since the AGP in colostrum from day 3 and day 5, and from 18 whey samples from mature milk, was not directly detectable, the one-step procedure of purification and concentration was set up. The boAGPenriched fractions were finally semi-quantified using the Radial Immunodiffusion test. The results are shown in Figure 1. The concentration of boAGP in colostrum 


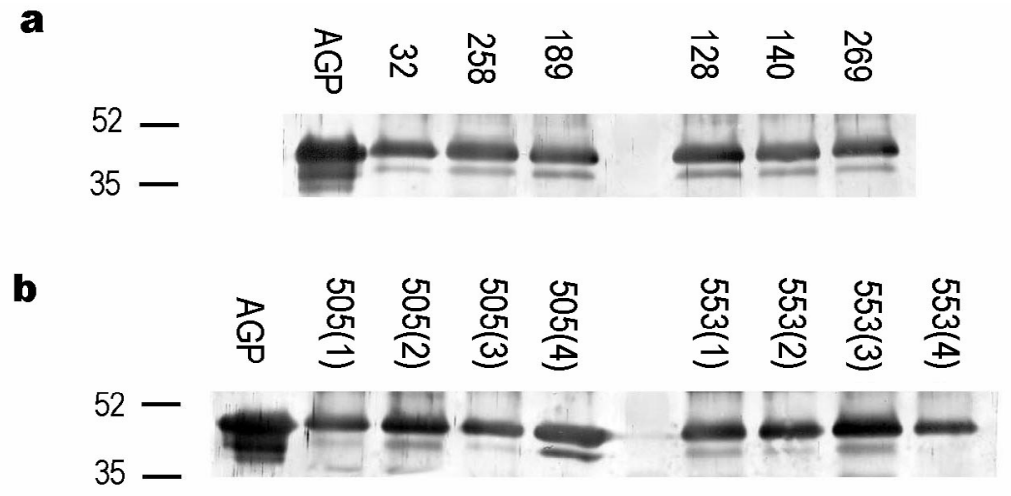

Figure 2. Western blotting of AGP from anion exchange chromatography and ultrafiltration. Lane AGP shows the Western blotting of $1.5 \mu \mathrm{g}$ of commercial boAGP. (a) Mature milk SDS-PAGE and Western blotting from fractions obtained after Q-Sepharose anionic-exchange chromatography from cows 32, 258, 189, 128, 140 and 269. $15 \mu \mathrm{g}$ were loaded on each lane. (b) Colostrum Western blotting from fractions obtained after Q-Sepharose anionic-exchange chromatography from cows 505 and $553(1=$ after $12 \mathrm{~h}, 2=$ after $24 \mathrm{~h}, 3=$ after 3 days, $4=5$ days $)$.

clearly decrease to $1.5 \mu \mathrm{g} / \mathrm{mL} \pm 0.6 \mu \mathrm{g} / \mathrm{mL}$ (day 3) and $1.2 \mu \mathrm{g} / \mathrm{mL} \pm 0.52 \mu \mathrm{g} / \mathrm{mL}$ (day 5).

The concentration in mature milk (SCC $<250000$ ) was also similar to colostrum $(1.2 \mu \mathrm{g} / \mathrm{mL}, \pm 0.69 \mu \mathrm{g} / \mathrm{mL})$. The concentration of AGP in bovine milk with low SCC $(<250000)$ was very similar to that from bovine with high SCC ( $>250000)$, which was determined as $1.3 \mu \mathrm{g} / \mathrm{mL} \pm 0.4 \mu \mathrm{g} / \mathrm{mL}$. It should be pointed out that these values were probably underestimated since the exact amount of boAGP in milk could not be determined, and therefore it was not possible to evaluate the yield of boAGP after the chromatographic step. We reduced the variability among the samples as much as possible by using the same staring amount (4 mL) of whey.

The bovine AGP expression in colostrum and milk was also analysed by Western blotting, using an anti-feline AGP polyclonal antibody that cross-reacts with boAGP (Fig. 2, lane AGP). All samples were analysed (10 colostrum and 18 milk samples). Figure 2 presents the Western blot of the proteins eluted from anionexchange fractions of some representative milk (Fig. 2a) and colostrum samples (Fig. 2b). In order to determine the specificity of the polyclonal antibody, $1.5 \mu \mathrm{g}$ of commercial boAGP were loaded. The WB analysis revealed that in the whole eluted fraction, a band of $45 \mathrm{kDa}$ with the same MW as the commercial boAGP was present. The data presented indicate that (a) boAGP is present in all colostrum and milk samples and (b) its MW is identical to that obtained from plasma (commercial boAGP).

\subsection{Purification and identification of bovine AGP in milk}

Bovine AGP was further purified as described in the Materials and methods section following three successive chromatographic steps, that allowed to obtain boAGP in the homogeneous form necessary for $\mathrm{N}$-terminal amino acid sequencing and the results are reported in Figure 3 . The boxed insert of Figure 3 presents the SDSPAGE of the three purification steps. The purification efficiency and recovery from $100 \mathrm{~mL}$ of milk whey is reported in Table II. The purification table lacks the information about the recovery of boAGP from milk whey after the first step, because the 

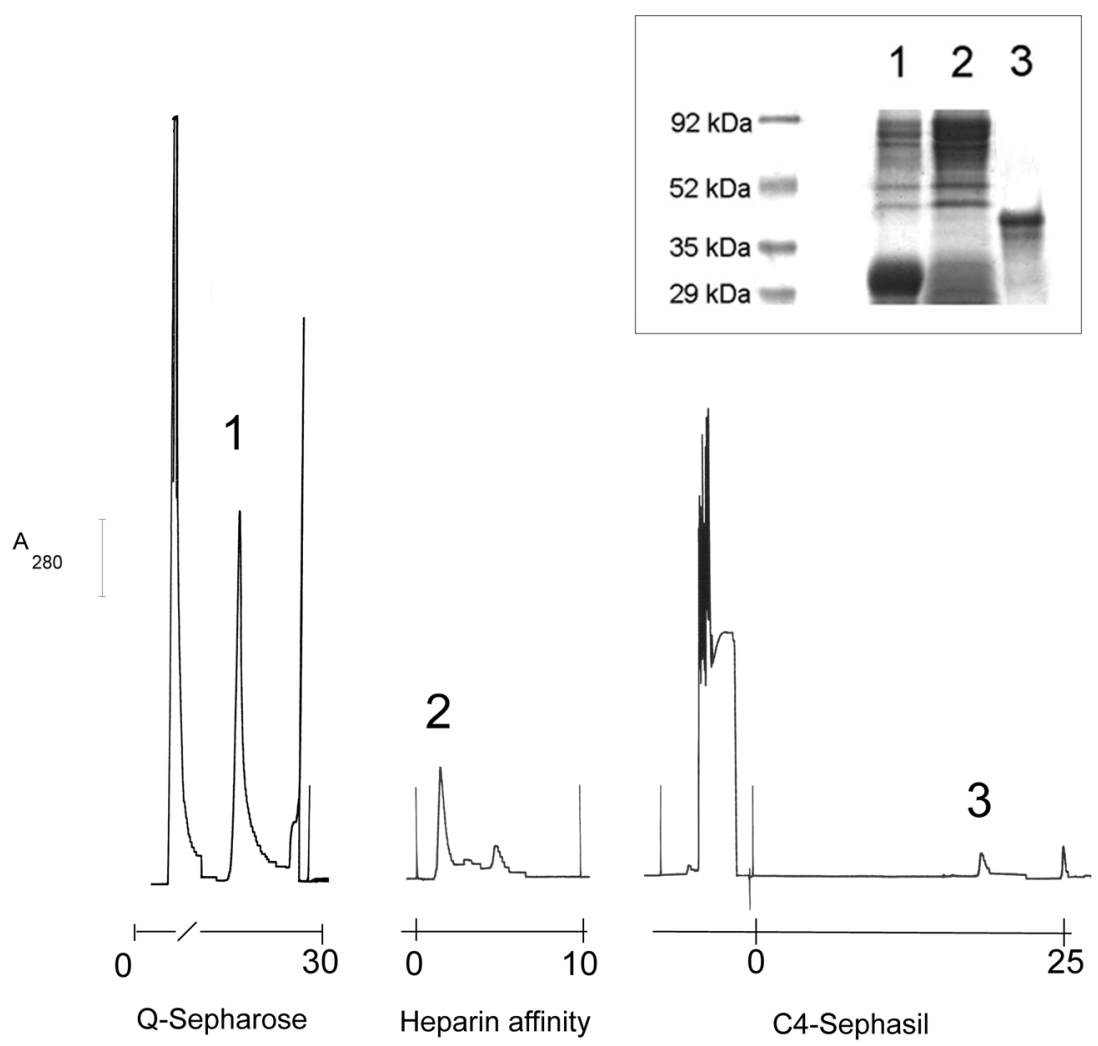

Figure 3. Purification of AGP from bovine milk. (1) Q-Sepharose Chromatography of bovine whey (3) Heparin Affinity Chromatography: the void volume chromatogram is presented. (2) Sephasil Protein C4. Boxed insert: SDS-PAGE of boAGP-containing protein fractions of each purification step Stained with Coomassie Blue. Molecular mass standards are shown in the first lane. Lane 1: fraction 1 from Q-Sepharose Chromatography. Lane 2: fraction 2 from Heparin Chromatography. Lane 3: fraction 3 from C4-Sephasil Chromatography.

boAGP content of whey is under the sensitivity limit of the detection kit. Therefore the yields were calculated starting with step 2 (Q-Sepharose chromatography).

Aliquots of boAGP from fraction 3 were subjected to (a) direct amino-terminal sequencing and (b) in situ fragmentation with $\mathrm{CNBr}$-formic acid followed by sequencing of the fragments.

Direct sequence analysis of boAGP gave no results, indicating that the amino-terminal residue of the protein was blocked. In situ fragmentation followed by the amino acid sequence resulted in a single the amino acid sequence of 11 residues, LAASXVGTKNV. A comparison of this sequence with the translated cDNA sequence of boAGP (presented below) revealed that the sequenced residues are identical to the sequence of boAGP starting from Leu 112. It can therefore be concluded that the purified protein from milk is bovine AGP.

\subsection{Determination of boAGP cDNA sequence}

The cDNA sequence of boAGP was determined with the walking primer method. 
Table II. Purification efficiency and recovery of AGP from $100 \mathrm{~mL}$ of bovine whey.

\begin{tabular}{lcccccc}
\hline Purification step & $\begin{array}{c}\text { Total volume } \\
(\mathrm{mL})\end{array}$ & $\begin{array}{c}\text { Total protein } \\
(\mathrm{mg})\end{array}$ & $\begin{array}{c}\text { Protein } \\
(\mathrm{mg} / \mathrm{mL})\end{array}$ & $\begin{array}{c}\text { BoAGP } \\
(\mu \mathrm{g} / \mathrm{mL})\end{array}$ & $\begin{array}{c}\text { Total boAGP } \\
(\mu \mathrm{g})\end{array}$ & $\begin{array}{c}\text { Specific yield } \\
(\mu \mathrm{g} / \mathrm{mL})\end{array}$ \\
\hline Q-Sepharose & $50 \mathrm{~mL}$ & 24.75 & 0.495 & 1.25 & 62.5 & 2.5 \\
He-Affinity & $35 \mathrm{~mL}$ & 1.35 & 0.04 & 1.21 & 42.2 & 31.4 \\
Sephasil C4 & $15 \mathrm{~mL}$ & 36.66 & 2.44 & 1.88 & 28.2 & 769 \\
\hline
\end{tabular}

The nucleotide sequence obtained with the first pair of primers was the starting point for the design of the second pair of primers. In order to determine the sequence of the first 48 bases of boAGP mature protein coding sequence, the third pair of primers was used. The strategy of the sequencing of boAGP, and the position of the degenerated primers, are summarised in Figure 4a, with the exception of primer F2, which was positioned from nucleotide 9 of the human AGP sequence, and is not shown in the Figure.

The nucleotide sequence of the fragment obtained from each PCR was subjected to a BLAST search in order to match AGP's sequence to that of other species. The four segments of boAGP were overlapped together in order to form a 658-bp cDNA sequence, shown in Figure 4a, that codes for an amino acid sequence of 219 residues. As deduced by sequence comparison with other proteins belonging to the AGP family, the mature protein starts at the first amino acid (Q) and ends with the first Stop codon and accounts for a MW of $20410 \mathrm{kDa}$. The cDNA sequence of bovine AGP has been deposited in the EMBL database under the accession number AJ844606.

Figure $4 \mathrm{~b}$ shows an alignment of boAGP with other known sequences. Eighty-four residues out of 185 are conserved, or conservatively substituted in all the proteins (45\% similarity).

Prosite analyses are shown in Figure 4b, and revealed five potential N-glycosylation sites at residues 17, 40, 77, 87 and 119 . Interestingly, bovine $\alpha_{1}$-acid glycoprotein shows seven potential phosphorylation sites: Ser24, Ser42 and Ser95 are Protein kinase C phosphorylation sites while Thr69,
Ser91 and Ser95 are casein kinase II phosphorylation sites. Finally, Lys179 is a cAMP- and cGMP-dependent protein kinase phosphorylation site. Surprisingly, the so called "Lipocalin signature", i.e. the motif that characterises the protein that transports small hydrophobic molecules, is absent in the boAGP. However, Figure $4 \mathrm{~b}$ shows that in other AGP sequences, in the mouse and rat for example, this lipocalin signature is also absent.

\subsection{Expression of AGP mRNA from Somatic cells and mammary tissue}

In order to investigate the origin of AGP in bovine milk, the expression of boAGP mRNA from mammary gland tissue and somatic cells was examined by RT-PCR (Fig. 5). RNAlater stored samples (mammary glands) revealed partial degradation of RNA, in particular in the 5' portion of the sequence. Two pairs of primers were therefore used: the first pair (AGP1F and AGP1R) for somatic cells, and the third pair of primers (AGPF3 and AGPR3b) for mammary gland samples (Tab. I). cDNA from the liver was used as a positive control in both PCR. The transcripts of the expected size (according to the boAGP cDNA sequence) were detected in tissues from all three mammary glands examined, but not in somatic cells. The very low expression of AGP in sample number 15 can be attributed to the partial degradation of mRNA from the mammary gland tissue. This degradation was particularly evident in sample number 15. The 350-bp PCR product (somatic cells and positive control) and 305-bp (mammary gland and positive control) were 


\section{a}

TGCGATAGACAGAGAGTCCCCGAGTGTGCCAACCTGATGACAGTGGCGCCCATTACCAATGCCACC

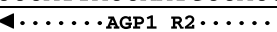
ATGGACTTGCTCTCTGGCAAGTGGTTTTATATTGGCTCCGCTTTCCGAAACCCCGAGTACAATAAG TCGGCTAGAGCAATCCAGGCGGCTTTCTTTTACCTTGAGCCCAGGCACGCAGAGGACAAGCTGATC ACCAGAGAGTACCAGACCATTGAGGACAAGTGCGTCTACAACTGCAGCTTCATAAAAATCTATCGT CAGAATGGGACCTTGTCTAAAGTTGAGTCGGACAGAGAACACTTTGTTGACCTGCTGCTCAGCAAG CACTTCAGGACCTTCATGCTTGCTGCCTCCTGGAATGGCACAAAGAACGTGGTCAGGGTGTCCTTC TATGCTGACAAGCCGGAGGTGACCCAGGAGCAGAAGAAAGAGTTCTTAGATGTCATCAAGTGCATA …..

GGCATCCAGGAATCAGAAATCATATACACTGACGAGAAGAAGGATGCGTGTGGGCCGCTGGAGAAG $4 \cdot \cdots$ AGP1 R1....

CAGCATGAGGAGGAAAGGAAGAAGGAGACAGAAGCGTCCTAGTATTGGGCCAGGATCCTGGGGGCT ACGATGGCCCACCCGCAGCCCCCTGCTCACTGTTTGTAACTCAGTTCCCTCACTTGCATCAATAAA A

b

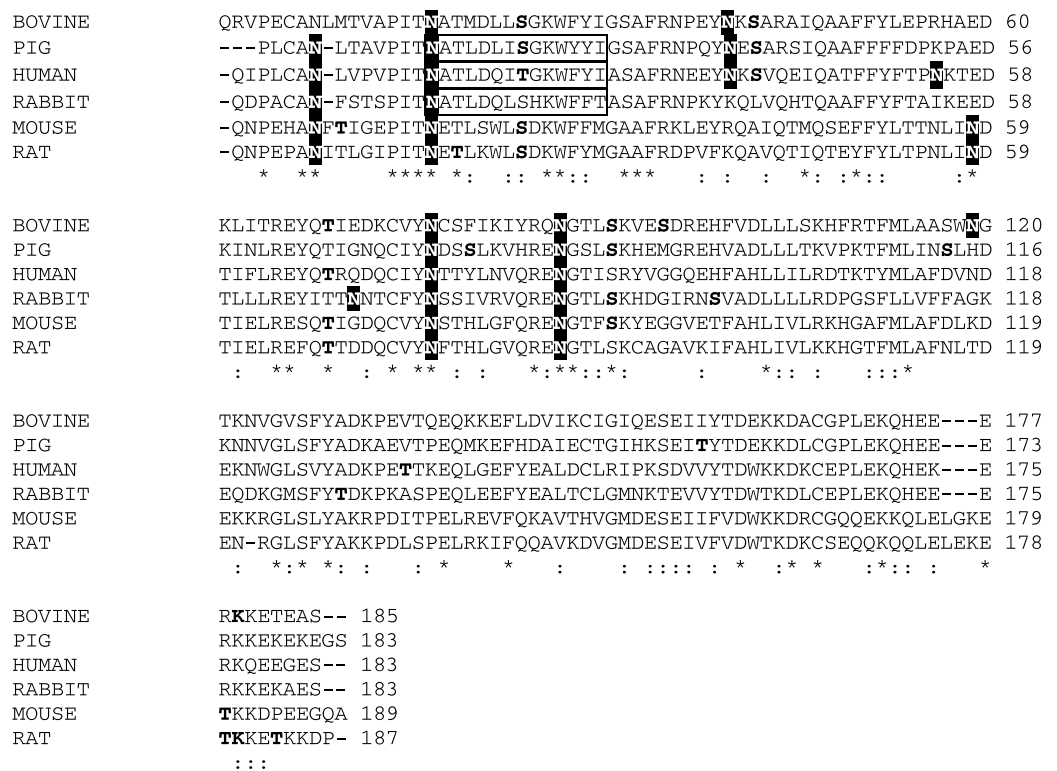

Figure 4. The primary structure of bovine AGP. (a) cDNA and amino acid sequence of mature bovine AGP from the liver. (b) Homology comparison of the primary structure of boAGP with that of other proteins belonging to the same family. The primary accession numbers (Swiss-Prot) are the following: pig: Q29014, human: P02763, rabbit: P25227, mouse: Q60590, rat: P02764. $\mathbf{N}$ indicates theoretical $\mathrm{N}$-glycosylation sites. In bold are indicate the potential phosphorylated positions as predicted by Prosite (Expasy). Identical residues are indicated with *. Conservative substitutions are indicated with :. The box indicates the lipocalin signature. 

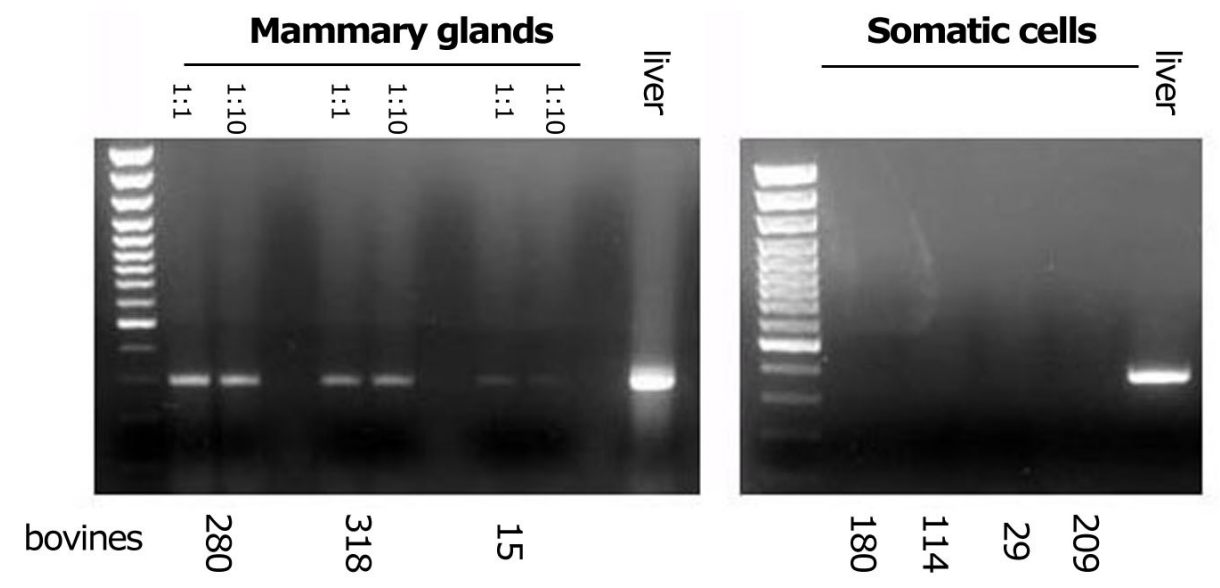

Figure 5. Expression of bovine AGP mRNA in mammary tissue and somatic cells. Two different DNA concentrations were used in mammary gland tissue, 1:1 and 1:10 dilution. Where not expressly indicated, a 1:1 dilution was used.

sequenced and compared with the boAGP sequence (Fig. 4a) in order to confirm the correct identities of the PCR products.

\section{DISCUSSION}

The "somatic cells" found in milk are composed mainly of cells of the immune system, milk macrophages $(66-80 \%$ in the milk of healthy cows, or of chronic mastitis affected cows) and neutrophils (>90\% in acute mastitis) [24]. These cells form one of the most important defence mechanisms in the udder. The ability of somatic cells to sequester and/or kill the pathogens is a critical step in the development of mastitis, and is strictly regulated by several host factors, including cytokines, soluble receptors and receptor antagonists that can increase, or inhibit, the immune defence in the mammary gland $[1,25]$. In the present study an immunomodulatory plasma protein, the $\alpha 1$-acid glycoprotein, was identified in colostrum and milk. Purification of the protein to homogeneity and internal sequence analysis further confirmed the identity of boAGP. The MW of $20.4 \mathrm{kDa}$, determined by the amino acid sequence derived from the cDNA sequencing of the boAGP gene, corresponds to the $20 \mathrm{kDa}$ of the deglycosylated polypeptide chain reported in the literature [16].

Bovine AGP was detectable by RID and WB in all tested samples. The concentration was very high during the first two days of lactation (colostrum) but significantly decreased in mature milk.

In order to investigate the origin of AGP in bovine milk, AGP gene expression in somatic cells and mammary tissues was examined. Our results revealed that AGP mRNA levels remained undetectable in somatic cells. This was not surprising, since the level of boAGP semi-quantified after a chromatographic concentration procedure did not increase in samples with high SCC. On the contrary, AGP gene expression was detected in all three mammary tissues used in this experiment. Nonetheless, these expression studies have to be repeated using bovine epithelial mammary gland culture, such as MAC-T for example, that have been reported to produce other APP (Serum Amyloid A protein) [21]. Moreover, a Real Time PCR approach, instead of the simple RT-PCR, may be useful in quantifying the amount of boAGP expressed by mammalian cells in different pathological conditions. 
What can the biological significance of the presence of AGP in milk be? We can only speculate about that. As an immunomodulatory molecule, boAGP could play several roles during inflammatory challenges in the mammary gland. For example, AGP has been shown to inhibit several activities of neutrophils [4, 34] that can cause severe cell and tissue damages in the mammary gland $[1,27]$. Moreover human AGP significantly inhibits the proliferation of peripheral blood T-cells [3], induces the expression of several pro- and anti-inflammatory cytokines by monocytes [31] and can directly antagonise the capillary leakage induced by some inflammatory mediators, such as histamine, platelet activating factor and bradykinin [22].

AGP might exert these activities not necessarily by increasing its expression rate, but also by modifying its glycan moiety. Acute phase reaction may lead to other alterations than concentration changes in heavily glycosylated proteins such as AGP, for example changes in glycan composition as shown for AGP in other species [32, 33]. To the best of our knowledge, only one paper is available reporting the differences in glycosylation patterns of boAGP from bovines of different ages [14] and this aspect should be investigated further. This paper also showed that boAGP can be found at high concentrations in colostrum in nonpathological conditions. Several components within colostrum can influence the immunological development of the offspring. The presence of several pro-inflammatory (IL-1 $\beta$, TNF- $\alpha$ ) and anti-inflammatory (IL-1Ra, TNF- $\alpha$ receptor I and II, and IL-10) molecules has been widely demonstrated in bovine colostrum [12]. These factors usually decrease in mature milk, and are likely to be involved in the development of the immature immune system of neonates. Interestingly, a very high level of serum AGP was found in calves (four times the adult value) [14] and piglets (40 times the adult value) [15]. Therefore, due to its immunomodulatory properties, it is conceivable that boAGP may also contribute to the com- plex framework of the immunoregulatory molecules expressed in bovine colostrum.

\section{ACKNOWLEDGMENTS}

We thank Prof. Saverio Paltrinieri and Dr Laura Kramer for the critical reading of the paper. We acknowledge the very precious gift of the anti-feline AGP from Dr Addie, Department of Veterinary Pathology, University of Glasgow, United Kingdom. This work was financed by Grant FIRST/2003 (F. Ceciliani), FIRB/2001 (P. Sartorelli) and COFIN 2003 (P. Sartorelli).

\section{REFERENCES}

[1] Burvenich C., Van Merris V., Mehrzad J., Diez-Fraile A., Duchateau L., Severity of E.coli mastitis is mainly determined by cow factors, Vet. Res. 34 (2003) 521-564.

[2] Ceciliani F., Faotto L., Negri A., Colombo I., Berra B., Bartorelli A., Ronchi S., The primary structure of UK114 tumor antigen, FEBS Lett. 393 (1996) 147-150.

[3] Chiu K.M., Mortesen R.F., Osmand A.P., Gewurz H., Interactions of $\alpha 1$-acid glycoprotein with the immune system. I. Purification and effects upon lymphocyte responsiveness, Immunology 32 (1977) 997-1005.

[4] Costello M.J., Gewurz H., Siegel J.N., Inhibition of neutrophil activation by alpha1-acid glycoprotein, Clin. Exp. Immunol. 55 (1984) 465-472.

[5] Eckersall P.D., Young F.J., McComb C., Hogarth C.J., Safi S., Weber A., McDonald T., Nolan A.M., Fitzpatrick J.L., Acute phase proteins in serum and milk from dairy cows with clinical mastitis, Vet. Rec. 148 (2001) $35-41$.

[6] Flower D.R., North A.C., Sansom C.E., The lipocalin protein family: structural and sequence overview, Biochim. Biophys. Acta 1482 (2000) 9-24.

[7] Fournier T., Bouach N., Delafosse C., Crestani B., Aubier M., Inducible expression of the $\alpha_{1}$-Acid glycoprotein gene by alveolar macrophages: prostaglandin $E_{2}$ and cyclin AMP act as new positive stimuli, J. Immunol. 163 (1999) 1883-2890.

[8] Fournier T., Medjoubi-N N., Porquet D., Alpha-1-acid glycoprotein, Biochim. Biophys. Acta 1482 (2000) 157-171.

[9] Gill H.S., Doull F., Rutherford K.J., Cross M.L., Immunoregulatory peptides in bovine milk, Br. J. Nutr. 84 Suppl.1 (2000) 111-117. 
[10] Gabay C., Kushner I., Acute-phase proteins and other systemic responses to inflammation, N. Engl. J. Med. 340 (1999) 448-454.

[11] Gendler S.J., Dermer G.B., Silverman L.M., Tokes Z.A., Synthesis of alpha 1-antichymotrypsin and alpha 1-acid glycoprotein by human breast epithelial cells, Cancer Res. 42 (1982) 4567-1573

[12] Hagiwara K., Kataoka S., Yamanaka H., Kirisawa R., Iwai H., Detection of cytokines in bovine colostrum, Vet. Immunol. Immunopathol. 76 (2000) 183-190.

[13] Hochepied T., Berger F.G., Baumann H., Libert C., $\alpha_{1}$-Acid glycoprotein: an acute phase protein with inflammatory and immunomodulating properties, Cytokine Growth Factor Rev. 14 (2003) 25-34.

[14] Itoh H., Tamura K., Izumi M., Motoi Y., Funayama Y., Characterization of serum alpha 1-acid glycoprotein in fetal and newborn calves during development, Am. J. Vet. Res. 54 (1993) 591-595.

[15] Itoh H., Tamura K., Izumi M., Motoi Y., Kidoguchi K., Funayama Y., The influence of age and health status on the serum alpha 1-acid glycoprotein level of conventional and specific pathogen-free pigs, Can. J. Vet. Res. 57 (1993) 74-78.

[16] Iwata H., Murase K., Inoue T., Monoclonal antibody against bovine alpha1-acid glycoprotein, J. Vet. Med. Sci. 62 (2000) 10991100 .

[17] Laemmli U.K., Cleavage of structural proteins during assembly of the head of bacteriophage T4, Nature 227 (1970) 680-685.

[18] Leutenegger C.M., Alluwaimi A.M., Smith W.L., Perani L., Cullor J.S., Quantitation of bovine cytokine mRNA in milk cells of healthy cattle by real-time TaqMan polymerase chain reaction, Vet. Immunol. Immunopathol. 77 (2000) 275-287.

[19] Logdberg L., Wester L., Immunocalins: a lipocalin subfamily that modulates immune and inflammatory responses, Biochim. Biophys. Acta 1482 (2000) 284-297.

[20] Matsudaira P., Sequence from picomole quantities of proteins electroblotted onto polyvinylidene difluoride membranes, J. Biol. Chem. 262 (1987) 10035-10038.

[21] McDonald T.L., Larson M.A., Mack D.R., Weber A., Elevated extrahepatic expression and secretion of mammary-associated serum amyloid A2 (M-SAA3) into colostrum, Vet. Immunol. Immunopathol. 82 (2001) 203211.

[22] Muchitsch E.M., Teschner W., Linnau Y., Pichler L., In vivo effect of alpha 1-acid glycoprotein on experimentally enhanced capillary permeability in guinea-pig skin, Arch. Int. Pharmacodyn. Ther. 331 (1996) 313-321.
[23] Nakano M., Kakehi K., Tsai M. Lee Y.C., Detailed structural feautures of glycan chains derived from $\alpha 1$-acid glycoproteins of several different animals: the presence of hypersialylated, O-acetylated sialic acids but not disialyl residues, Glycobiol. 14 (2004) 431-441.

[24] Östensson K., Hageltorn M., Astrom G., Differential cell counting in fraction-collected milk from dairy cows, Acta Vet. Scand. 29 (1988) 493-500.

[25] Paape M.J., Bannerman D.D., Zhao X., Lee J.W., The bovine neutrophil: structure and function in blood and milk, Vet. Res. 34 (2003) 597-627.

[26] Petersen H.H., Nielsen J.P., Heegaard P.M., Application of acute phase protein measurements in veterinary clinical chemistry, Vet. Res. 35 (2004) 163-187.

[27] Shuster D.E., Kehrli M.E., Rainard P., Paape M., Complement fragment C5a and inflammatory cytokines in neutrophil recruitment during intramammary infection with Escherichia coli, Infect. Immun. 65 (1997) 32863292.

[28] Sordillo L.M., Shafer-Weaver K., DeRosa D., Immunobiology of the mammary gland, J. Dairy Sci. 80 (1997) 1851-1865.

[29] Sörensson J., Matejka G.L., Ohlson M., Haraldsson B., Human endothelial cells produce orosomucoid, an important component of the capillary barrier, Am. J. Physiol. 276 (1999) 530-534.

[30] Tamura K., Yatsu T., Itoh H., Motoi Y., Isolation, characterization, and quantitative measurement of serum $\alpha_{1}$-acid glycoprotein in cattle, Nippon Juigaku Zasshi. 51 (1989) 987-994.

[31] Tilg H., Vannier E., Vachino G., Dinarello C., Mier J.J.W., Antiinflammatory properties of hepatic acute phase proteins: preferential induction of interleukin 1 (IL-1) receptor antagonist over IL-1 beta synthesis by human peripheral blood mononuclear cells, J. Exp. Med. 178 (1993) 1629-2636.

[32] Van Dijk W., Havenaar E.C., Brinkman-van der Linden E.C., Alpha 1-acid glycoprotein (orosomucoid): pathophysiological changes in glycosylation in relation to its function, Glycoconj. J. 12 (1995) 227-233.

[33] Van Dijk W., Brinkman-Van der Linden E.C.M., Havenaar E.C., Glycosylation of alpha(1)-acid glycoprotein (orosomucoid) in health and disease: Occurrence, regulation and possible functional implications, Trends Glycosci. Glycotechnol. 10 (1998) 235-245.

[34] Vasson M.P., Roch-Arveiller M., Couderc R., Baguet J.C., Raichvarg D., Effects of $\alpha_{1}$-acid glycoprotein on human polymorphonuclear neutrophils: influence of glycan microheterogeneity, Clin. Chim. Acta 224 (1994) 65-71. 